\section{A mídia eletrônica à luz das tochas: um estudo de comunicação, cotidiano e mitologia}

\section{RESUMO}

A referência aos arquétipos, imagens mitológicas, símbolos e alegorias tem sido um expediente recorrente nos estudos de comunicação, cultura e sociedade, propiciando vertentes metodológicas de fôlego, que não raro, têm engendrado muitas investigações consistentes. Aqui utilizamos as noções e conceitos caros ao "jogos de linguagem" da investigação científica e nos remetemos também às metáforas presentes na imaginação mitológica, acreditando que a sabedoria encantada das mitologias tem servido não apenas como vetor de prescrição de "uma moral da história" ou como um refúgio que reconforta o espírito; consiste, sobretudo, numa sabedoria que participa também da formação de um campo crítico em que proliferam a dúvida, 0 questionamento e 0 ceticismo.

\section{ABSTRACT}

This paper analyses the inspirational role of arquetypes, mythic images, symbols and allegories in the study of human com-munications, culture and society.

\section{PALAVRAS-CHAVE (KEY WORDS)}

- Mitos (Myths)

- Comunicação (Human communications)

- Estudos Culturais e Sociais (Cultural and Social studies)

\section{Cláudio Paiva}

Departamento de Comunicação - UFPB
Imaginação científica e sabedoria encantada da mitologia

"Há milênios, muito antes de esse corpo de conhecimento que hoje chamamos de ciência existir, a relação dos seres humanos com o mundo era bem diferente. A natureza era respeitada e idolatrada, sendo a única responsável pela sobrevivência de nossa espécie, que vivia basicamente da caça e de uma agricultura rudimentar. $\mathrm{Na}$ esperança de que as catástrofes naturais como os vulcões, tempestades e furacões não destruíssem as suas casas e plantações, ou matassem os animais e os peixes, várias culturas atribuíram aspectos divinos à natureza. (...) em certas culturas, vários deuses controlavam (e até personificavam) as diferentes manifestações culturais, enquanto em outras a própria natureza era divina, a "Deusa-Mãe". Rituais e oferendas procuravam conquistar a sua existência, dando sentido a fenômenos misteriosos e ameaçadores. Por outro lado, a relação com os deuses tinha também uma função social, impondo valores morais e éticos que eram fundamentais para a coesão do grupo. Essa relação religiosa com a natureza se estendia para além das funções mais imediatas do bem-estar e segurança do grupo, abrangendo também as necessidades de ordem 
mais metafísica. Um exemplo disso é a interpretação da morte em diferentes religiões. Em certos casos, a morte é apenas uma passagem para uma nova vida, uma ponte ligando uma existência à outra, em um ciclo que se repete eternamente. Em outros, a morte representa uma ascensão a uma realidade absoluta, a promessa de uma merecida existência eterna no Paraíso, após as várias atribulações e dificuldades da vida. Qualquer que seja a cultura, a busca pela compreensão da morte através da religião satisfaz a necessidade que temos de lidar com o que é tantas vezes imprevisível e inexplicável. Para o crente, a fé conforta e dá a certeza de que a sua própria morte não é o fim de tudo. Já para o cético, a própria ciência pode oferecer algum conforto. (...) nos defrontamos com uma barreira intransponível que tem suas origens no modo como pensamos e nos comportamos em sociedade: o problema da polarização entre pares de opostos imbuída na nossa percepção da realidade. Quando tentamos entender e organizar o mundo à nossa volta, a distinção entre opostos é fundamental. Nossa existência e ações são rotineiramente baseadas em pares opostos, como dia e noite, frio e quente, culpado e inocente, feio e bonito, morto e vivo, rico e pobre. Sem essa distinção os nossos valores não teriam sentido, nossa agricultura não funcionaria, e nossa espécie provavelmente não sobreviveria. O problema é que pagamos um preço por sermos assim. Perguntas que transcendem a distinção entre opostos ficam sem resposta. (...) A necessidade de entendermos nossa origem e a origem de todo o universo, ou seja, o problema da Criação, é inerente ao ser humano, transpondo barreiras temporais e geográficas. Ela estava presente há milênios, quando nos abrigávamos em cavernas durante tempestades, e ela está presente agora, quando encontramos tempo para refletir sobre nossa existência. Uma vez que nos perguntamos sobre a origem do universo, encontrar uma resposta se torna muito tentador. (....) o veículo encontrado por várias culturas foi o mito. Os mitos são histórias que procuram viabilizar ou reafirmar sistemas de valores, que não só dão sentido à nossa existência como também servem de instrumento no estudo de uma determinada cultura. (Muitos) exemplos mostram que o poder do mito não está em ele ser falso ou verdadeiro, mas em ser efetivo. (...) na cosmogonia moderna, encontramos alguns traços dessas idéias antigas, memórias distantes talvez, que de alguma forma permaneceram vivas nos confins de nosso inconsciente, demonstrando uma profunda universalidade da criatividade humana".

Marcelo Gleiser, A Dança do Universo, 1997.

2 A aparição dos mitos no universo da comunicação

As mitologias hoje, como ontem, participam de uma imaginação criativa que confere sentido à existência. A "ciência com consciência", como escreve Edgar Morin, livre dos preconceitos, abriga as intuições, dúvidas, ironias e apostas da sabedoria comum; assim em nosso estudo da ficção televisiva seriada, o enfoque das mitologias nos parece estratégico para vislumbrarmos as formas de revelação e de ocultação do "mundo real"1.

Relembramos, a propósito, que o pensador Michel Serres se utiliza das inúmeras divindades e figuras lendárias realizando abstrações refinadas para tratar do fenômeno da comunicação; Serres 
recorre à figura de Dom Juan, como o mestre da sedução e dos disfarces, mas sobretudo, no livro "Hermes e a Comunicação" (1968), remonta ao deus Hermes ou Mercúrio, em sua acepção latina ${ }^{2}$. O discurso de Serres é propositadamente articulado através de uma fina ironia, situando a comunicação no âmbito da comédia, ou seja, por meio de um discurso de transgressão; a comunicação é vista por Serres sob a ótica de Hermes, pai da hermenêutica, ciência da interpretação dos textos sagrados e pagãos; é o deus do comércio, dos viajantes e dos ladrões ${ }^{3}$. Hermes preserva ainda a significação dos textos herméticos, dos mistérios e da iniciação; isto, de certo modo, transparece de modo atualizado - nas imagens de ficção seriada da televisão ${ }^{4}$. Em sua acepção latina, como Mercúrio, a divindade nos permite ler os processos de comunicação em sua natureza mercadológica, isto é, em seu aspecto ágil e comutativo, numa significação que remete à idéia de "mercearia", ou seja, de mercado, troca, partilha, numa imagem que antecipa a visão da sociedade dos fluxos, das conexões e das redes.

Encontramos nas reflexões de Adorno e Horkheimer uma filosofia da consciência empenhada em resgatar o "espírito das Luzes" para esclarecer os indivíduos imersos na alienação, como se mostra na obra "A Dialética do Esclarecimento"5. Para isso, os filósofos recorrem ao mito da Odisséia, ao personagem do herói, encarnado por Ulisses e aos ardis da razão dialética como estratégia de emancipação da espécie humana. Para não ceder ao canto das sereias, Ulisses, ordena que os marujos coloquem cera nos ouvidos e que o amarrem ao mastro do navio, conseguindo assim sobreviver utilizando-se da razão para superar o perigo causado pelo canto das sereias. Essa é a grande metáfora que orienta os frankfurtianos, obsediados pelo fantasma de uma mitologia perigosa; tendo sofrido na pele a experiência do nazismo, têm verdadeira "fobia" pelas mitologias e chegando aos Estados Unidos, na década de 40, iriam se apavorar com o poder da televisão e a expansão da cultura de massa ${ }^{6}$. Desde as obras de crítica da filosofia da consciência, sociologia do conhecimento e estudos estéticos até suas formulações sobre a ética e "a personalidade autoritária", Adorno, particularmente, se dedica à desmontagem dos mitos, vistos como expressões de uma falsa consciência da realidade ${ }^{7}$.

De maneira análoga, Jean Baudrillard, o filósofo da iconoclastia pós-moderna, inspirado num filme expressionista dos anos 30, "O estudante de Praga", atualiza uma leitura do mito do Fausto e suas negociações macabras com Mefistófeles, numa modulação particular do diabo moderno. "A Sociedade de Consumo" (1975), livro básico de Baudrillard, se conclui numa apreciação dessa fábula insólita, em que o indivíduo vende a sua imagem ao diabo, em troca do sucesso e da obtenção dos bens materiais; mas este acordo implica a perda da sua própria imagem, sua identidade, ou seja, não pode se ver, nem pode re-conhecer a si mesmo. Isso traduz um pouco a "crítica radical" de Baudrillard à realidade assediada por simulacros e simulações que, ao seu ver, encarnam as formas das mitologias contemporâneas, afetando de maneira negativa a consciência social; essas idéias persistem de maneira irônica nos seus textos mais recentes, como "O Crime Perfeito" e "Tela Total, Mito-ironias do Virtual"8.

Baudrillard tematiza criticamente as mitologias fazendo uma sociologia iconoclasta e denunciando os simulacros como vetores de regressão; aliás, isto é algo que ele herdou, certamente, de seu "orientador", Roland Barthes, para quem as mitologias aparecem como espécies de "falas roubadas" das narrativas históricas, científicas, religiosas, literárias, filosóficas, ou seja, como um produto ideológico das classes dominantes; como podemos ler no livro "Mitologias" (1957) e no estudo 
posterior "A mitologia hoje", $1987^{9}$.

Os exemplos de recorrência aos temas mitológicos para o entendimento do fenômeno da comunicação são infindáveis e possuem sentidos muito diferentes. No que diz respeito à linha de pesquisa que reúne "Linguagem e Comunicação", a simbologia da Torre de Babel ocupa um lugar de destaque. Esta imagem aparece em diversas modulações, como expressão do caos e da desordem, como figuração dos reveses do destino; a exemplo do paraíso perdido, do dilúvio, no livro do Gênese, Babel surge como uma dimensão decadente e regressiva da humanidade ${ }^{10}$. Aqui, aliás, temos uma dupla acepção mítica das imagens da Torre e de Babel; a torre, na astrologia, aparece como a torre fulminada que emana os presságios de crise, infortúnio e desgraça ${ }^{11}$. $\mathrm{O}$ atentado que fulminou as torres do World Trade Center, visto repetidamente pelas televisões do mundo, viria a atualizar e intensificar esse arquétipo no imaginário ocidental. A palavra "Babel", por sua vez, tende a aparecer na imaginação popular como uma zona de turbulência, desordem e confusão. Mas à visão poética cabe libertar o sentido das palavras e as coisas da sua dimensão restrita, dominante e definitiva. Assim, numa direção oposta, para o escritor Jorge Luis Borges, o arquétipo da Biblioteca de Babel ilustra a experiência comunicacional em sua dimensão hermética, misteriosa e iluminada, constituída de forma hexagonal, formando um grande labirinto, como enigma e desafio; é uma imagem, portanto, que emana um aspecto de afirmação e positividade, remetendo a uma experiência da comunicação orientada pela lucidez, clarividência e sabedoria; ver "A biblioteca de Babel", $1986{ }^{12}$. Dessa fonte poéticoliterária exuberante, que "brilha como a pureza de um diamante", Umberto Eco soube recolher sua inspiração. A bibliotecalabirinto de alvéolos hexagonais, descrita por Borges, como uma Babel fecunda, serve de base erudita para a realização do romance "O Nome da Rosa", adaptado para o cinema. A imagem arquetípica da Biblioteca de Babel, com U. Eco, adquire os contornos de uma obra popular pósmoderna, que em última instância, realiza uma ponte entre os relatos medievais e as narrativas urbanas contemporâneas; relembramos que "O Nome da Rosa" (1980) mantém traços da poesia provençal de "O Romance da Rosa", da Idade Média e simultaneamente, contém recursos tácteis, acústicos e audiovisuais da cultura pop internacional, o que certamente favoreceu o êxito de sua transposição para o cinema, no filme homônimo de Jean Jacques Annaud, em 1986 ${ }^{13}$.

Mobilizados pelo espírito crítico, há diversos autores que têm referido o mito de Frankenstein, a lenda de "o médico e o monstro", para discutir a relação entre o criador e a criatura. Aqui temos, então, um desdobramento da reflexão sobre as relações míticas entre os humanos e as divindades, mas que se atualizam, na época da clonagem genética, através das relações entre os homens e as novas tecnologias. Essa imagem aparece hoje com força poética, na banalidade eficiente da narrativa da telenovela "O Clone" (Glória Perez, 2002).

Nessa direção, citaríamos os estudos do comunicólogo francês Lucien Sfez, principalmente, a "Crítica da Comunicação" (1992), para quem a condição do homem contemporâneo se traduz, sob a forma do "tautismo" (contração entre a "tautologia" e o "autismo"), com nítidos matizes negativos. Sfez entende os processos comunicacionais de nossa época como elementos de regressão e faz sua denúncia; entretanto, assume posteriormente, em 1993, uma postura mais compreensiva, na obra de fôlego, "Dicionário Crítico da Comunicação"14. Em linhas gerais, podemos perceber as referências mitológicas, no campo da comunicação e das tecnologias, sob uma aura de mau presságio. Se para Adorno e Horkheimer, o mito das sereias ressurge como pretexto de exorcismo da ignorância pela razão esclarecida e 
há autores que fazem ligações entre o desenvolvimento tecnológico e a fábula sinistra de Frankenstein; outros ainda se referem às alianças entre as tecnologias e o mal. Relembramos, a propósito, Norbert Wiener, o autor de um livro clássico no campo da comunicação, "Cibernética e Sociedade" (1952); Wiener, na obra "Deus e o Golem", inspirado nas lendas populares de tradição judaica, remonta à figura de um andróide místico como metáfora para tratar das criações cibernéticas, e então reflete sobre o risco moral de se exagerar acerca dos efeitos gerados pelas "máquinas de comunicar". Wiener, nessa obra de caráter ambíguo, chamava a atenção, em 1964, para a "importância vital do elemento humano" e para o perigo da substituição do homem pela máquina ${ }^{15}$.

Mais recentemente o teórico da comunicação Muniz Sodré recorreu ao mito de Narciso para refletir sobre os temas da televisão, indivíduo e poder no Brasil, numa obra sintomaticamente intitulada "Máquina de Narciso"16. Trata-se de um estudo de fôlego que instiga reflexões teóricometodológicas sobre as modalidades de interação e exclusão dos indivíduos na época das tecnologias da informação e da comunicação.

Aqui, buscando manter um diálogo entre os regimes da imaginação científica e o imaginário da mitologia, remontamos ao mito grego de Dionísio, procurando perceber como são instauradas as formas de sociabilidade e de comunicabilidade, em meio aos processos midiáticos. Trata-se de uma investigação apoiada em diversas contribuições interdisciplinares, que coloca em relevo os elementos mitológicos estruturantes da ficção seriada televisiva e, em última instância, remete ao imaginário coletivo brasileiro.

3 O dionisismo, a atração e a ira comunitária

Uma das nossas bases interpretativas se ancora num ponto de vista estético para compreender o homem em sociedade e elegemos a noção de "imagens dionisíacas" para traduzir a complexidade da cultura brasileira. Ou seja, procuramos nos deter sobre a maneira como os indivíduos formam suas percepções e compreensões da realidade, a partir dos afetos, sentimentos e emoções; isto é, uma faculdade de sentir que se revigora no contato com as imagens projetadas na TV. Neste sentido, ao longo da história das culturas, as mitologias encarnam uma dimensão essencialmente estética, animando as representações literárias, musicais, pictóricas, cinematográficas e televisuais; aqui, uma "teoria do sensível" antes que uma "teoria do belo" ilumina a nossa vontade de saber.

Retomamos o mito do deus grego Dionísio (ou Baco, na terminologia latina) para focalizar o imaginário social brasileiro, e seguindo este fio, observamos as tribos urbanas à luz do sincretismo religioso, sensualidade e cultura de natureza selvagem.

Situamos essas imagens no contexto das tecnologias da imagem e da comunicação, no domínio da ficção televisiva; tal empresa parece, em princípio, um contra-senso, porque a mídia eletrônica é vista antes como uma instância de individualização do que um vetor de sociabilidade; depois porque a mídia tende a neutralizar os conflitos e mostrar as imagens do social de forma espetacular. Além do mais, a televisão, privilegiando o olhar sobre os demais sentidos, estimularia uma experiência mais apolínea (de harmonia visual, narcisista, conformista) do que dionisíaca (impulsiva, catártica, liberadora).

O nosso desafio consiste em mostrar que, apesar de todos os cuidados técnicos e ideológicos da mídia, reencontramos no espaço das telenovelas a possibilidade de flagrar a expressão do dionisíaco, uma experiência multissensorial, com todos os termos de perigo e violência que povoam 
a vida social, sem descartar a sua parte de fascínio e beleza.

\section{Aparência de felicidade e tragédia da cultura}

O desejo de felicidade, a vontade de eternidade, a busca da paixão amorosa e o entusiasmo da experiência tribalizada conferem um sentido afirmativo à vida, levam os indivíduos ao culto dos mitos. A imaginação mitológica que teve lugar na Grécia antiga, sob outras modulações, chegou à modernidade e hoje se encontra em plena efervescência.

O mundo encantado dos heróis e dos deuses do Olimpo povoou o imaginário dos homens antigos, como espécies de janelas para fugir das sombras do tempo, das ações do destino, dos limites da existência e da finitude humana; por outro lado, mais do que um refúgio, as mitologias têm funcionado como um tipo de mediação que serve de orientação nos percursos da vida cotidiana.

Podemos perceber o espírito do tempo dos antigos marcado por um caráter politeísta aberto às diversas formas de contemplação da vida. O historiador Paul Veyne mostra que, mesmo à época clássica, a linguagem mitopoética coexistia ao lado dos discursos filosóficos, medicinais, pedagógicos e políticos ${ }^{17}$.

Sob as luzes da modernidade, a emancipação do gênero humano através do progresso da ciência, organização sociopolítica e do liberalismo econômico animou o imaginário social; igualmente, a promessa de felicidade contida na profusão material dos objetos industrial-tecnológicos passou a fascinar os indivíduos ocidentais, desde fins do século XIX, com a emergência da chamada "sociedade de massa".

Nesse contexto, reina um espírito científico que rege a maneira moderna de compreender o mundo, e ele é da ordem da demonstração, explicação, controle e dominação. É uma perspectiva que se constitui enquanto um regime de pensamento regido pelo monoteísmo, pelo unitário, pelo absoluto; o que este cogito não pode organizar, classificar e demonstrar relega ao terreno da superstição e da irracionalidade. Hoje, no terceiro milênio, experimentamos a sensação de que a idéia do futuro, tal qual havíamos concebido antigamente, já pertence ao passado e a idéia de progresso, se não abolida inteiramente, tem sido bastante relativizada. Não há mais etapas históricas a serem superadas na longa escada civilizatória. Diante da virtualidade de uma terceira guerra mundial entre a civilização industrialtecnológica e as culturas tradicionais dos fundamentalistas, a noção de "progresso" mantém-se sob suspeita e o conceito de "desenvolvimento", por sua vez, solicita uma direção e sentido que legitimem a sua permanência e sustentabilidade. Deste modo, hoje assistimos a um certo retorno daquilo que a civilização moderna tinha desprezado, ou seja, as mitologias e as religiões reaparecem para suprir as lacunas deixadas pela "racionalidade técnica", que regeu o imaginário ocidental no tempo forte da modernidade. Assim, o mito de Dionísio é resgatado aqui cumprindo a função de estimular uma dupla compreensão do êxtase e do mal-estar na contemporaneidade.

"Quem é Dionísio? O deus do êxtase e do terror, da selvageria, da libertação mais bendita, o deus louco cuja aparição provoca o delírio dos homens, anuncia desde a sua concepção e seu nascimento o caráter enigmático e contraditório do seu ser. Ele era filho de Zeus e de Sêmele, uma mulher mortal. Mas antes mesmo de Ihe dar à luz, ela foi consumida pelos raios de Zeus, seu esposo celeste"18.

Revisitamos o mito de Dionísio no entrecruzamento de textos diversos 
que nos permitem decifrar as pistas e significações que este mito traduz desde as fases arcaicas do homem em estado de tribalização primeva. Os autores antigos como Eurípedes ("As Bacantes") e Ovídio ("As Metamorfoses"), assim como diversos estudiosos e intérpretes das mitologias, têm persistido no esforço de interpretar e compreender os sentidos do rito e do mito de Dionísio, nos diferentes estágios da história da cultura. Inúmeros autores têm mostrado a passagem da sociedade agrícola à sociedade urbana, apontando como os cultos primitivos às divindades da natureza, num mundo outrora "bárbaro", mas que se tornando "civilizado" adquire novas tonalidades. Muitos estudos - como o de Jeanmaire - nos apresentam como as manifestações éticas, religiosas e políticas, contidas no mito dionisiano, subvertem as regras da "democracia" na antiguidade clássica; e revelam como não apenas a tragédia, mas também a comédia contribuiu para a crítica e questionamento dos valores hegemônicos na Grécia antiga, enunciando uma forma de exercício da experiência política, atenta aos valores estéticos, religiosos e morais ${ }^{19}$. Hoje, vários pensadores têm resgatado o deus Dionísio, percebendo as suas emanações nas diferentes expressões do atual e cotidiano; eles nos permitem compreender como esta figura arquetípica, evidente no cinema e na televisão, evoca as aparências de felicidade e de tragédia da cultura, gerando uma sinergia que agrega as diferentes sensibilidades dispersas na cartografia das cidades.

\section{A história do mito de Dionísio e suas aparições na idade mídia}

Particularmente, Dionísio aparece na obra de Maffesoli, leitor de Nietzsche, consistindo numa importante visão filosófica e social do mito e sua ritualística, fonte recorrente em nossa pesquisa e argumentação ${ }^{20}$. Destacamos alguns episódios - em diversos outros textos - que nos parecem importantes e nos servirão como indícios para compreender o simbolismo da cultura brasileira, que entendemos como dionisíaca. Assim, os signos da vida, da morte, do renascimento, da metamorfose, do erotismo, do êxtase místico e religioso, da ecologia, das paixões amorosas, assim como aqueles do eterno retorno e da vida indestrutível, presentes na transposição do texto de Maffesoli "A sombra de Dionísio", aqui nos são valiosos numa interpretação da ficção brasileira.

Todavia, segundo as mais amplas e diversas interpretações da mitologia, por exemplo, segundo Pierre Grimal, Dionísio é o filho de Zeus (Júpiter para os latinos) e de uma bela mortal chamada Sêmele, uma princesa tebana; é o fruto de uma paixão que despertou os ciúmes de Hera (Juno, na acepção latina). Conta a lenda que num sonho, Hera, ciumenta, apareceu a Sêmele e lhe sugeriu de pedir a Zeus para que este se mostrasse a ela, em toda sua potência. Zeus amava Sêmele e tinha prometido não the recusar nada. Sêmele, então, grávida de seis meses, pereceu fulminada, incapaz de suportar a visão dos raios e trovões que emanavam do seu amante. Zeus se apressou em arrancar a criança que ela portava no ventre e o costurou na coxa esquerda; três meses depois ele veio ao mundo em melhores condições. Há outras versões do mito que recorrem a imagens diferentes na explanação do nascimento de Dionísio; contudo, o que interessa reter aqui é o sentido da força dessa imagem, que remete à postura do homem diante da consciência da própria finitude e a sua vontade de imortalidade; essa imagem arquetípica é ritualizada hoje, permanentemente, pelos ícones da cultura de massa. Então, eis a origem de Dionísio, aquele que nasceu duas vezes. Após o seu nascimento, Dionísio foi confiado ao deus Hermes, que lhe entregou ao rei Átamas, rei Beócio da Queronéia, casado com Ino, irmã de Sêmele, para que cuidassem da sua educação; ali, Zeus, então, sugeriu 
que vestissem Dionísio em trajes femininos para que este escapasse da fúria de Hera $^{21}$. Uma psicologia das profundezas - a partir de Jung - nos autoriza a interpretar a imagem de androgenia de Dionísio como um exemplo de "coincidência dos opostos", presente na essência de diversas divindades; ou seja, trata-se de uma conjunção entre o "animus" (a dimensão masculina dos seres) e a "anima" (a sua dimensão feminina) que assegura o equilíbrio dos seres no longo ciclo do nascimento, vida, reprodução, morte e renascimento ${ }^{22}$.

No campo dos estudos de mitologia, encontramos muitas referências ao fenômeno da androgenia, que para os antigos encontra o seu fundamento nos mitos da criação. Segundo a versão de Hesíodo, na "Teogonia", tal imagem traduz um tipo de perfeição: Cronos (o Tempo) teria engendrado o Ovo Cósmico contendo simultaneamente o dia (o princípio masculino) e a noite (o princípio feminino) ${ }^{23}$. Este arquétipo reaparece em diversas modulações, nas culturas antigas e nas culturas recentes, como uma "coincidência de opostos", união dos extremos que atualizaria a grande conjunção do mundo cósmico. Relembramos, a propósito, o estudo de Mircea Eliade, "Mefistófeles e a androgenia" (1960), em que o mitólogo se dedica a refletir sobre este arquétipo, visto aqui como um vetor de revelação dos mistérios da "renovação cósmica" e da "totalidade primordial"24. A propósito, a projeção do mito da androgenia no mundo das artes pictóricas, poéticas, literárias e cinematográficas é analisada com rigor no livro de Dominique Fernandez, "O Rapto de Ganymedes" (1989); como se sab,e Ganymedes para os antigos era uma criança andrógena, considerado o mais belo dos mortais, que despertou as atenções de Zeus; e este, transformado em águia, terminou levando consigo o adolescente para o Olimpo, após seduzi-lo, segundo as versões de Ovídio, Hesíodo, Eurípides, entre outros ${ }^{25}$.
O mito da androgenia tem sido bem recorrente no cinema e na televisão; às vezes a sua configuração mantém um sentido compreensivo e tolerante, em analogia às interpretações derivadas do "ovo cósmico", ou seja, como um arquétipo que conjuga os opostos; outras vezes, porém, aparece sob o signo da tradição judaico-cristã e tende a engendrar formas bizarras de intolerância e de preconceitos. No cinema, as suas expressões marcantes se fazem presentes, por exemplo, nos filmes "Morte em Veneza" (Luchino Visconti, 1971), "A Dança dos Vampiros" (Roman Polanski, 1967), "Maurice" (James Ivory, 1987), "Victor ou Vitória", (Blake Edwards, 1982), entre outros; na ficção televisiva brasileira, apareceu em títulos como "Renascer" (Benedito Ruy Barbosa, 1993), "Grande Sertão Veredas" (Walter George Durst, 1985), "O Rebu" (Bráulio Pedroso, 1974/75), "A Próxima Vítima" (Sílvio de Abreu, 1996) e "As Filhas da Mãe" (Abreu, 2002).

Em meio aos diversos textos filosóficos que tratam da questão do "dionisíaco" e das figuras mitológicas que possuem significações análogas, a obra de Marcuse "Eros e Civilização" (1981), particularmente o capítulo intitulado "As imagens de Orfeu e Narciso", sinaliza novas direções para uma pesquisa, principalmente considerando-se o vigor com que o autor trata do mito de Eros, como motor das transformações contraculturais, no contexto da sociedade industrial dos anos 60/70; Marcuse apreende aqui o sentido do Eros em sua função catártica e libertadora ${ }^{26}$. Num outro registro, encontramos num autor como Nicolau Sevcenko a recorrência aos mitos antigos como uma leitura crítica e compreensiva das culturas urbanas, na obra "Orfeu extático na metrópole"27.

A história de Dionísio é marcada por uma trágica perseguição: Hera, apercebendo-se das trapaças de Zeus, enlouqueceu Ino, a ama de Dionísio, e o seu marido, Átamas,que no fim das contas tiveram uma morte trágica. Precavendo- 
se, Zeus transforma Dionísio em bode e pede para que Hermes transporte a criança para o Monte Nysa, longe da Grécia, deixando-o aos cuidados das ninfas e dos sátiros, que lá habitavam uma gruta. As diversas transformações pelas quais passou o deus evidentemente possuem um sentido específico no domínio das culturas antigas; mas conviria retermos aqui a sua significação num contexto mais universal, ou seja, como imaginação da vontade de longevidade ${ }^{28}$.

Essa concepção reaparece em Nietzsche, no livro de Zaratustra que "começa pelo relato de três metamorfoses, (mostrando) como o camelo se torna leão, e como o leão se torna criança. $O$ camelo é o animal que carrega o peso dos valores estabelecidos, os fardos, carrega a crítica de todos os valores estabelecidos. Cabe ao leão se tornar criança, realizar novo jogo e novo recomeço, criar novos valores e novos princípios de avaliação"29.

Observamos as metamorfoses humanas no corpo das narrativas de ficção da TV, sob o signo da transformação dos homens e mulheres em figuras animalescas, seres imaginários e sobrenaturais, e percebemos como o sentido das mitologias contemporâneas consiste numa repetição e atualização dos mitos antigos. Encontramos a expressão do arquétipo das metamorfoses em diversas imagens ficcionais, por exemplo: na narrativa de "Saramandaia" (1976), em que o personagem de Gibão (Juca de Oliveira) se transforma em pássaro; em "Roque Santeiro" (1985/86), as transformações do lobisomem nas noites de lua cheia; em "Pantanal" (1990), o velho do rio se transformando em cobra sucuri e a mulher (Cássia Kiss) virando onça; em "A Indomada" um rapaz (Selton Melo) se transforma num anjo, que reaparece quando a sua amada toca flauta. Os exemplos são inumeráveis e confirmam a presença das metamorfoses como um elemento estrutural e permanente da imaginação simbólica que se atualiza na linguagem mítica da telenovela.

$\mathrm{Na}$ idade adulta, Dionísio descobriu a videira e inventou o vinho. Hera, prosseguindo em sua vingança, enlouqueceu Dionísio. Em sua loucura, Dionísio atravessou o Egito, a Síria e chegou à Ásia, onde foi recolhido pela deusa Cibele, que lhe purificou e o iniciou nos ritos de seu culto. Aqui temos a trajetória de um ritual que colocou em xeque a supremacia da experiência místicoreligiosa prevalente; como o candomblé, no Brasil, que partindo - em princípio - dos cultos religiosos marginalizados, pouco a pouco foi se configurando fortemente como expressão legítima da sensibilidade mística popular.

Aqui temos um amplo repertório de signos que se deslocam dos antigos aos contemporâneos: Nietzsche fala da embriaguêz metaforicamente como um artifício que abre as portas da percepção, estimulando, por exemplo, a dramaturgia e a criação artística, em "A Origem da Tragédia" ${ }^{30}$. Mas aqui, sobretudo, temos os traços de sincretismo de uma religião pagã ou panteísta, com nítidos traços hedonistas, o dionisismo cultiva o uso dos prazeres e simultaneamente mantém uma ligação mística com as forças da natureza; isto é algo que encontramos, por exemplo, na sociedade brasileira contemporânea, animada pelo culto dos Orixás. Quanto aos aspectos de errância e nomadismo, caracterizados no mito dionisíaco, eles remontam aos ritos de iniciação e de transcendência que inspiram a humanidade. Nas diversas passagens das ficções seriadas, flagramos os personagens nômades que se desterritorializam buscando encontrar os seus próprios caminhos; apontamos nessa direção a telenovela "O Astro" (Janete Clair, 1977-78), em que o personagem Márcio Ayala (na pele do ator Tony Ramos) se despe literalmente dos bens materiais, abandona a casa dos pais, e como uma espécie de Sidharta ou S. Francisco pósmoderno, parte em busca de si mesmo. 
Num outro registro, encontramos na série "Ciranda Cirandinha" (1978) as tribos dos jovens que se lançam às ruas receptivos a uma nova experiência de sociabilidade. A leitura proposta por Michel Maffesoli no livro "Vagabondages Initiatiques" (1997) nos concede as chaves para compreendermos essa angulação das imagens dionisíacas na errância das experiências nômades e transitórias da pós-modernidade ${ }^{31}$.

Em suas errâncias, conta a lenda que, livre da loucura, Dionísio chegou à Trácia, onde foi mal recebido pelo rei Licurgo e este tentou aprisioná-lo; mas Dionísio fugiu, sendo recolhido por Tétis, a nereida, que Ihe deu asilo no fundo do mar. Contudo, o rei Licurgo capturou as Bacantes, servas de Dionísio, que conseguiram fugir; em seguida, Licurgo foi atingido pela loucura: amputou a própria perna, assim como as extremidades do corpo do seu filho, pensando abater a vinha e percebeu ainda que o seu país tinha sido atingido pela seca. O oráculo, interrogado, revelou que a fúria dionisíaca seria paziguada se o rei fosse sacrificado. Assim foi feito: o rei foi esquartejado por quatro cavalos selvagens. Da Trácia, Dionísio partiu para a Índia, um país que ele já tinha conquistado pela força de um exército, encantamento e pela potência mística.

De retorno à Grécia, Dionísio partiu para a Beócia (região da Grécia Central), lugar de origem da sua mãe; em seguida foi para Tebas (no Egito), onde governava Penteu (o sucessor de Cadmos). Lá então, ele introduziu os bacanais, festas em homenagem ao seu culto e seduziu o público, sobretudo as mulheres, que foram arrebatadas pelo delírio místico. O rei Penteu opôs-se a estes ritos e foi punido, sendo atingido pela loucura, assim como a sua mãe Agave que o despedaçou em várias partes.

Todo o aspecto de violência e horror contido na dramatização da tragédia dionisíaca serve como metáfora do sacrifício, aplacando a violência dos homens e alerta para as passagens mútuas entre os ciclos da natureza selvagem e da "cultura civilizada".

Como o princípio dionisíaco é alimentado pelas forças espontâneas da natureza, possui evidentemente a sua parte vitalista e a sua parte mortífera; o dionisismo, que encarna também a parte bestial dos seres humanos, contém uma dimensão feroz e violenta e traduz as pulsões selvagens do indivíduo e o seu descontentamento na ordem da cultura, algo que Freud trata literalmente de modo terapêutico em "O mal-estar na civilização"36. Aliás, Freud percebe este "mal-estar da civilização" como resultado do represamento das pulsões violentas, a parte selvagem do inconsciente e da cultura, e propõe a psicanálise como uma terapia que viria curar as neuroses, geradas por esse "mal-estar" ou "descontentamento".

Outros pensadores, como Nietzsche, vêem a própria domesticação dos costumes como uma encarnação da violência contra a vontade potência do homem - relembramos que para ele, Sócrates, como Cristo, realizou uma violência contra a consciência trágica (e encantada) do mundo e reclama uma filosofia do "anticristo", que traria de volta o homem superior, o super-homem ${ }^{33}$. Assim, há encontros e confrontos entre Freud e Nietzsche, que têm norteado especulações filosóficas e investigações científicas sobre as "aparições das imagens dionisíacas na cultura civilizada"34. De nossa parte, nos detemos num enfoque do dionisíaco como uma experiência que abrange as dimensões místico-religiosas, sensuais, eróticas, ecológicas e políticas como exercícios da vontade de potência, cujas origens estão no inconsciente dos indivíduos e da cultura. Como tudo isso contém os resíduos da parte primitiva, animal, selvagem no ser humano, a sua aparição não poderia se realizar de maneira harmônica e pacífica, pois desestabiliza a ordem social, política e cultural prevalente. Entretanto, por meio das brechas da cultura civilizada penetram as imagens do entusiasmo, do êxtase e do arrebatamento 
que não podem ser contidas pelas regras da civilização (o carnaval, o futebol e as telenovelas, neste sentido, teriam aqui uma função importante). As obras de arte, incluindo aí as poéticas tecnológicas da televisão, realizam um tipo de exibição das imagens extremas, as quais denominamos "imagens dionisíacas", que podem vir a estimular diferentes modalidades de educação estética e liberar as experiências de catarse dos telespectadores.

\section{Omedodoespedaçamentoeatomização do corpo}

A leitura do mito de Dionísio segundo alguns mitólogos como Marcel Détienne, que se refere à outra versão da lenda, ou seja, da criança divina despedaçada pelos titãs, serve de metáfora para o eterno ciclo de ordem e desordem na organização do universo ${ }^{35}$. O sacrifício do pequeno Dionísio abrange as dimensões do horror e do êxtase contidos nos sacrifícios religiosos. $\mathrm{O}$ fato de os titãs devorarem os pedaços de Dionísio, após os cozinharem e em seguida os assarem, traduz toda uma imaginação da passagem das culturas ditas "bárbaras" às ditas culturas "civilizadas", mas se refere também ao repertório dos regimes alimentares como metáfora para a distinção dos diferentes estágios do homem em relação à sua vida terrena e sua elevação existencial numa cadeia cósmica. Tal metáfora, que contém grande parte da estrutura de funcionamento da pólis antiga, foi encarnada em diversas tragédias (como "As Bacantes", de Eurípides) e aparece em comédias (como "Os Sapos", de Aristófanes), remontando a essa idéia da ascensão e declínio das civilizações em analogia aos modos de composição e recomposição da ordenação cósmica ${ }^{36}$.

Quanto à representação do delírio místico nas artes antigas, esta tem a função de amenizar as pulsões agressivas do social, mas, ao mesmo tempo, consiste em algo que desestabiliza a ordem social, política e moral - ao invés de cultivar a supremacia dos olimpianos, a dramatização trágica do mito de Dionísio mantém uma maior proximidade com a existência terrena dos seres humanos. Ali se colocam em cena as representações do eterno ciclo da natureza em seus aspectos de construção e destruição, mostram as formas de rebeldia e de resistência face aos desígnios do Destino e da vontade dos deuses; reside aí a sua dimensão política. Ali também se exibe a desordem das paixões eróticas e do êxtase amoroso, mas também as forças de horror e de violência, além do louvor à fertilidade, reprodução e longevidade (em sua dimensão sociocultural e cósmica). Percebemos que as visões de mundo dos antigos se atualizam - permanentemente - na época dos audiovisuais, ou seja, as tensões e conflitos sobre o indizível, aquilo difícil de explicar e de ser resolvido pela lógica científica permanece como um malestar que precisa de um cenário para se descomprimir e se pronunciar: a tragédia "resolvia" esse problema intensificando a representação das tensões e conflitos dos humanos face à inexorabilidade do destino determinado pela vontade dos deuses. $\mathrm{Na}$ comédia antiga, por sua vez, a estratégia do riso funcionava como um destravamento dessas tensões, invertendo os valores, desmontando as regras do jogo, virando do avesso a filosofia, a política, a religião e os costumes - e tem em Aristófanes o seu maior expoente. Nos séculos XX e XXI, isto se expressa na publicização do cinema e na televisão, através de autores como Dias Gomes, Aguinaldo Silva e Guel Arraes; assim, um olhar mais apurado percebe que a repetição teatral dionisíaca se faz presente nas cenas triviais do cotidiano.

\subsection{Narrativas mitológicas e narrativas históricas}

Nas diversas passagens do mito de Dionísio podemos observar algumas imbricações entre os nexos da mitologia e 
da história, ou seja, temos um enfoque da história da cultura e da civilização por um viés diferente dos marcos cronológicos, documentos históricos, monumentos, personagens e falas solenes. $\mathrm{O}$ mito de Dionísio consiste na rememoração das imagens que, aparentemente, revelam as experiências dos indivíduos guiados pelo "princípio do prazer", pulsões hedonistas e atividades orgiásticas. Mas convém perceber neste culto uma consciência extrema da realidade. No dionisismo os antigos realizam uma inversão: ao invés dos cultos idealistas em louvor às divindades regentes da sublimação e do ascetismo, deslocam-se para as partes baixas e enfatizam os valores terrenos, através da deusa Rhéa, Démeter (ou Ceres, para os romanos), enfim, a Grande Mãe, a Deusa Terra ${ }^{37}$. Por conseguinte, voltamse para a dimensão orgânica da vida, a agricultura, a fertilidade, a reprodução, decomposição e recomposição da ordem cósmica. Mas, sobretudo, ritualizam o vigor da vida a partir da consciência místicoreligiosa que abrange a sensualidade, 0 erotismo, a sexualidade, ou seja, "o vivo do sujeito"; assim, o dionisismo encarna uma "materialidade mística" que se aproxima bastante de diversas experiências dos indivíduos na sociedade contemporânea.

Relendo Nietzsche, encontramos a apreciação dessa ética-estética em que a dimensão apolínea, socrático-platônica, cristã cede lugar à dimensão dionisíaca, material, orgânica e panteísta. Nietzsche remonta ao plano da representação trágica, através do êxtase dionisíaco que arrebata os indivíduos por meio de uma estética afirmativa. Ou seja, os humanos têm consciência de sua finitude e de sua impotência face às figuras do Destino, mas ao invés de se orientar através de uma visão da felicidade projetada na idealização de uma vida pós-morte, exercem com júbilo e contentamento a faculdade da vida no próprio acontecimento da existência terrena. Isto é algo que reaparece com força hoje, por exemplo, num produto de ficção audiovisual como "O Auto da Compadecida".

O aspecto de violência contido no mito de Dionísio por um lado dramatiza a própria dimensão agressiva dos seres humanos que destroem os seus semelhantes, o seu meio ambiente e conseqüentemente a sua própria espécie, como mostra o sociólogo André Akoun, em sua leitura dos "Mitos e Tradições da Europa"38; por outro lado, este rito contém uma dimensão de "sacrifício", que funciona como um tipo de exorcismo do mal, como Jesus Cristo, que teria morrido na cruz para redimir os pecados dos homens.

Por exemplo, em Argos, Dionísio se manifestou duramente: o rei Proetos viu suas filhas enlouquecerem, junto com outras mulheres, que passaram a mugir como vacas e devoraram os seus próprios filhos. Em seguida, Dionísio passou por Naxos (a maior das ilhas Ciclades) ajudado por piratas; entretanto, estes quiseram vendê-lo como escravo. Dionísio os puniu, transformando os remos em serpentes e paralisando o seu barco. Os piratas enlouqueceram, jogaram-se ao mar e se transformaram em golfinhos. Após este episódio, Dionísio foi reconhecido por todo mundo e ascendeu aos céus, após ter estabelecido o seu culto.

Contudo, antes ele quis reencontrar a sua mãe, Sêmele, e Ihe restituir a vida; ele passou pelo lago de Lerne, um lago sem fundo, com uma via de acesso para o mundo infernal. No Hades, Dionísio pediu ao deus dos infernos pra que este the devolvesse a sua mãe; este lhe consentiu, sob a condição de que Dionísio lhe desse algo de precioso. Dionísio escolheu a mirta entre suas plantas prediletas e a ofereceu ao deus. Assim, Dionísio subiu aos céus, levando consigo a sua mãe, que desde então permanece entre os olimpianos, após o perdão de Hera. Ou seja, as fases de ascensão e decadência da humanidade se revezam permanente como expressões da agonia e do êxtase dos humanos; guardadas as proporções de dois gêneros 
narrativos que se distinguem no tempo e no espaço, o dionisismo antigo reaparece hoje no contexto midiático das ficções seriadas. Se é verdade que a maioria destas ficções se exibe em suas formas apolíneas, edulcoradas e conformistas, mostrando os "meios como massagens", por outro lado, as imagens dionisíacas ali se fazem presentes, pois traduzem as dimensões dos afetos e sensações sob a forma da ternura e da brutalidade.

Sabe-se que o mito de Dionísio é muito rico; segundo a tradição órficopitagórica, Dionísio é filho de Zeus e Perséfone (a divindade responsável pelas estações do ano). Nesta lenda, Hera entrega a criança aos titã que o despedaçam, mas a deusa Atenas Palas apanha o seu coração ainda palpitando e o entrega a Zeus, que o fecunda em Sêmele; como no caso das divindades de Osíris e Shiva, também despedaçados, isto tem um sentido místico. Nestes diversos cultos, persiste a intenção de exorcizar o medo do homem diante da morte, da decomposição e da dispersão do corpo físico. Mas por outro lado, remete à temperança e ao equilíbrio necessários sobre a relação para consigo mesmo, para com o Outro, o social e o cósmico (a sua angulação comunitária). A imagem de Dionísio "feito em pedaços" aponta para a necessidade dos homens de realizarem um sacrifício que projeta as pulsões agressivas do animal contidas no ser humano. Isto se exibia na tragédia antiga e hoje, evidentemente, aparece sob diversas modulações, no cinema de Hollywood e nas telenovelas da Rede Globo; esta seria uma modulação afirmativa da violência na mídia.

Deus do vinho, da inspiração, do entusiasmo, Dionísio é também o deus das máscaras e do teatro; ele divide com Apolo o dom da música e é, igualmente, o deus da vegetação e da fertilidade. Num outro nível de abstração, o mito de Dionísio remete à questão do orientalismo; não podemos esquecer que o dionisismo é um culto estrangeiro, vindo do Leste, da Ásia Menor, do Oriente, e só tardiamente passou a fazer parte do repertório grego e latino. Nos textos antigos encontramos um conjunto de narrativas que expõem as tensões entre 0 culto dionisíaco e a civilização ocidental. Hoje, de certo modo, os conflitos entre os imaginários e as vivências do Ocidente e do Oriente refazem os termos dessa oposição milenar. É preciso não perder de vista que o dionisismo se assemelha ao orientalismo, no que diz respeito ao seu caráter de alteridade frente à cultura ocidental; relembramos que Dionísio é uma divindade que vem do Oriente. Ele não é originalmente grego, mas um composto de diferentes hibridações místico-religiosas, que passo a passo se instala na pólis grega e posteriormente em Roma, e persiste numa longa "farra", descomprimindo a rigidez das civilizações ocidentais, como atestam, por exemplo, os espetáculos do carnaval, do futebol, das olimpíadas e dos grandes conglomerados coletivos.

A conexão entre o dionisismo e o orientalismo aqui é pertinente, pois diz respeito às relações entre a lógica ocidental (européia e americana) e as maneiras de ser e de pensar dos "outros" (incluindo os africanos, os latinos e os orientais). Parecenos relevante apontar a conexão entre o mito de Dionísio e o orientalismo em nosso estudo da cultura de massa, principalmente num momento em que a opinião pública internacional repensa e rediscute as relações políticas e culturais entre o Oriente e o Ocidente, após o atentado terrorista contra os Estados Unidos, em 11 de setembro de 2001. Em verdade, o episódio possui um caráter histórico, político e transcultural de importância, na medida em que atualiza - de maneira radicalizada - um tipo de resistência extrema à hegemonia de um sistema de pensamento que também radicalizou o projeto de dominação do homem e da natureza.

Hoje, o êxtase e a fúria de Dionísio mostra-se, por exemplo, nos filmes de catástrofe norte-americanos ou nas ficções do realismo fantástico da televisão 
brasileira, como "Fogo sobre Terra" (197475), "Saramandaia" (1976), "Deus nos acuda" (1993), "A Indomada" (1997) e "O Fim do Mundo" (2000). Isto funciona como expressão do imaginário que se reconforta, ironiza e se deleita na imaginação de um "ajuste final" entre os homens e os deuses, entre a cultura e a natureza, na segurança de uma representação distante, na tela ou no vídeo. É algo que se mostra na temperatura quente do dia-a-dia, nos concertos de música pop que arregimentam legiões, nos momentos decisivos das partidas de futebol - que reúnem galeras e tribos indiferenciadamente e, sobretudo, na grande festa do carnaval, que configura o social de "cabeça pra baixo", invertendo derrisoriamente a rotina mecânica, certinha e bem-comportada da vida cotidiana.

No princípio do século XXI assistimos a uma nova modulação do dionisismo, como um conjunto de discursos e práticas que sempre atraíram e fascinaram, mas que também continuam a inquietar e assustar a cultura ocidental. Para pensadores e estudiosos como Freud, Marcuse, Theodor Roszak, Norman Brown, entre outros, o dionisíaco coloca em risco a estabilidade da civilização prometéica, estruturada sobre a produção industrial tecnológica e a "ideologia" da felicidade esboçada na realização do progresso e do desenvolvimento ${ }^{39}$. Convém assinalar que a racionalidade iluminista de estilo cartesiano e incluindo aí - analogicamente - a racionalidade pragmática americana sempre colocaram sob suspeita a sensualidade, a sensibilidade e a intuição criadora; esses termos aparecem no cogito ocidental como inimigos da consciência. Por outro lado, reconhecemos que tudo isso reaparece fulminantemente na liberação das artes literárias, dramatúrgicas e audiovisuais; contudo, sempre que procurou se expressar nos atos de linguagem e nas ações da vida cotidiana, com a "geração beat" (nos anos 50), os hippies (nos anos $60 / 70$ ) e os agenciamentos contraculturais dos anos 80/90, houve fortes resistências.
As instituições do saber (e do poder) oferecem resistência e reprimem as concepções que tendem a colocar em risco a legitimidade dos poderes estabelecidos; isto se fez notar na universidade medieval, aconteceu também nas academias da modernidade e, evidentemente, ainda se faz presente nas diversas instituições contemporâneas. Percebemos, todavia, que o distanciamento experimentado pela academia - durante tanto tempo - em relação ao conhecimento comum que considera a intuição, religiosidade e a sensualidade que estrutura toda a vida em comunidade, cede lugar a uma abertura de espírito que busca apreender a "lógica do vivido", em toda sua complexidade. Isto aparece com evidência nos textos de Simmel, Morin e Maffesoli40.

Num outro pólo, a razão sensível da latinidade, particularmente a sua vertente tropical, de maneira híbrida, sempre buscou conciliar os opostos; isto se comprova, por exemplo, examinando-se como a infraestrututra científico-tecnológica evolui na proximidade das forças da natureza, tal o exemplo do campo da engenharia solar, no Nordeste brasileiro; da medicina alternativa que engendra novas terapias à base de produtos naturais, nas experiências educativas do projeto Rondon, em que a aprendizagem se faz no contato direto com as populações das regiões menos industrializadas. Tudo isso confere uma natureza específica ao conjunto de discursos e práticas socioculturais brasileiros, que historicamente têm definido um estilo de vida singular, possuindo analogias com as formas do dionisismo e do orientalismo. Numa utilização particular, remontamos ao pensador orientalista Edward Said, autor de importantes estudos culturais, percebendo o dionisismo como uma modulação do orientalismo, que nos serve de parâmetro para refletirmos sobre a representação e a alteridade de outras culturas e sociedades; sua teoria nos ajuda a repensar a atualidade das relações entre o poder e o conhecimento, o papel do 
intelectual, do intérprete, do pesquisador e do artista; assim como auxilia a recolocar as questões metodológicas referentes às relações entre os diferentes tipos de textos ficcionais, históricos, científicos, entre o mito, a sociedade e a história da cultura ${ }^{41}$.

\section{$7 \quad$ Dionísio enamorado}

Há uma versão para a mitologia de Dionísio que celebra o seu encontro com Ariadne; esta, enquanto apaixonada pelo herói Teseu, salva a sua vida fornecendo-lhe um fio que Ihe permitiria escapar do labirinto após matar o Minotauro. Os dois foram felizes por um bom tempo, mas Teseu abandonou Ariadne adormecida no campo, deixando a bela desesperada, após ter perdido o seu amor juvenil. Porém, Dionísio a encontra e lhe mostra um outro lado do amor amadurecido, numa dimensão afirmativa da vida. Assim, superando as ilusões do amor idealizado, Ariadne contrai matrimônio com Dionísio, que a leva consigo para perto dos deuses. Entretanto, a mitologia, cumprindo a sua função de despertar os indivíduos do sono dogmático da "racionalidade abstrata", alerta para o eterno retorno de Dionísio em todas as épocas por meio das artes, que se mostram cruéis e necessárias por meio da tragédia, e também irônicas e subversivas através das comédias. Em nossos dias, Dionísio retorna na ficção televisiva no contexto de ambos os gêneros promovendo as formas do êxtase e do arrebatamento que irradiam a sociedade brasileira.

A paixão amorosa entre Dionísio e Ariadne nos remete à imagem do amor verdadeiro, que - para os antigos - passa pelo crivo do amor físico e fornece pistas aos contemporâneos, para a compreensão do amor sábio. Mas num outro registro, leva a pensar também sobre as relações entre a imaginação ardilosa, eficiente e utilitária (da ciência) e a imaginação espontânea da sabedoria popular (que inclui as mitologias); esta passagem - em última instância - remete às ligações entre a ciência e a filosofia, que transcende a metáfora do pensamento na passagem pela caverna da especulação (em Platão), como um exercício de aprendizagem à experiência do morrer (com Montaigne) e como vigor e exaltação do milagre da vida (através de Nietzsche).

\section{Notas}

1 MORIN, E. Ciência com consciência. Rio de Janeiro: Bertrand Brasil, 1998.

2 SERRES, M. "Le don de Dom Juan". In: Revue Critique, Ed. Minuit, mars., 1968; __ Hermes et la communication. Paris: Minuit, 1968.

3 GRIMAL, P. Dicionário da mitologia grega e romana. Rio: Difel, 1993; BRANDÃO, J. S. (1998). "Hermes Trimegisto". In: _- Mitologia Grega. Petrópolis: Vozes, 1998, ga ed., p. 191-208; DURAND, G. "Le XXème siècle et le retour d'Hermès". In: Figures mytiques et visages de l'oeuvre, De la mythocritique à la mythanálise. Paris: DUNOD, 1992 (1979), p. 268-340.

4 COURE, Marilou Manzini. No caminho de Hermes e Sherazade: cultura, cidadania e subjetividade. Taubaté: S.Paulo: Vogal, 1996.

5 ADORNO, T. "A indústria cultural". In: $\mathrm{COHN}, \mathrm{G}$. (org.) Comunicação e Indústria Cultural. S. Paulo: Ed. Nacional, 1977, p. 287-295; _ Mínima Moralia, Réflexions sur la vie mutilée. Paris: Payot, 1983; ADORNO, T; HORKHEIMER, M. "O lluminismo como mistificação de massa". In: COSTA LIMA, L. (org.) Teoria da Cultura de Massa. Rio de Janeiro: Paz e Terra, 1982, p. 159-206.

6 ADORNO, T. "Televisão, Consciência e Comunicação". In: COHN, G. (Org.) Comunicação e Indústria Cultural. S. Paulo: Ed. Nacional, 1977, p.346-354.

7 ADORNO, T. Mínima Moralia, Réflexions sur la vie mutilée. Paris: Payot, 1983.

8 BAUDRILLARD, J. "Da alienação contemporânea ou 0 fim do pacto com o diabo". In: A Sociedade de Consumo. 
Lisboa: Edições 70, 1975; __ Le Crime Parfait. Paris: Galilée, 1994; _ Tela Total, Mitoironias do Virtual. Porto Alegre: Sulina, 1997.

9 BARTHES, R. Mitologias. Rio: Bertrand Brasil, 1993; _ "A mitologia hoje". In: 0 rumor da língua. Lisboa: Edições 70, 1987, p. 63-66.

10 BALMARY, Marie. "Le sacrifice interdit". In: Freud et la Bible. Paris: Grasset, 1986.

11 NICHOLS, Sallie. Jung e o Tarô - Uma aventura arquetípica. S. Paulo: Cultrix, 1980.

12 BORGES, Jorge Luis. "La Biblioteque totale". In: Oeuvres Complètes de Borges, la Bibliotèque de la Pléiade, Gallimard.

13 ECO, U. O Nome da Rosa. S. Paulo: Nova Fronteira, 1980; __ Apostille au Nom de la Rose. Paris: Grasset, 1985.

14 SFEZ, L. (org.) Crítica da Comunicação. S. Paulo: Loyola, 1992; _ Dictionnaire Critique de la Communication. Paris: P.U.F., 1993, tomes 1 e 2.

15 WIENER, N. Cibernética e sociedade. S. Paulo: Cultrix, 19[-]; BRETON, P. "La cybernétique ou l'émergence de l'idée moderne de communication" in HENNEBELLE, Guy (org.) Les Théories de la Communication. Paris: Revue CinémAction, $n^{0}$ 63, mars., 1992, SFSIC-CorletTélérama. WIENER, N. God and Golem. Cambridge: MIT Press, 1964. Segundo as antigas lendas judaicas, inspiradas no misticismo da Cabala, seria possível dar vida a uma criatura, feita com pedaços de cadáveres, para defender o povo judeu. Tal criatura, ou "Golem", teria sido criada em 1580 por um rabino chamado Loew, conforme relato que Paul Wegener ouviu no Gueto de Praga, e que inspirou o roteiro de sua adaptação cinematográfica da lenda. (...) O Sepher Yetzirah é considerado um texto da Cabala meditativa com fortes sobretons de magia. Assim expressam as primitivas tradições talmúdicas, que indicam que ele podia ser utilizado para a criação de criaturas vivas. Significativas são as muitas referências e lendas de que o Sepher Yetzirah podia ser utilizado para criação de um Golem, uma espécie de andróide místico. Ver a propósito o site: http://www.eon.com.br/cia80.htm capturado em agosto de 2001.

16 MUNIZ SODRÉ. Máquina de Narciso, Televisão, Indivíduo e Poder no Brasil. Rio: Achiamé, 1984.

17 VEYNE, P. Acreditavam os gregos nos seus mitos? S. Paulo: Brasiliense, 1984.

18 OTTO, W.F. Dionysos, le mythe et le culte. Paris: Gallimard, 1969.

19 JEANMAIRE, H. Dionysos, Histoire du Culte de Bacchus. Paris: Payot, 1993 (1951); KERÉNYI, C. Dionysos, archetypal image of indestructible life. New Jersey: Princeton University Press, 1976; TRIOMPHE. Promethée et Dionysos ou la Grèce à la lueur des torches. Strasbourg: P.U.S., 1992; BRUN, J. Le retour de Dionysos. Paris: Desclée de Brouwer, 1969; DÉTIENNE, M. Dionysos mis à mort. Paris, Seuil, 1979; _ Dionysos à ciel ouvert. Paris, Hachette, 1986; DANIÉLOU, A. Shiva et Dionysos. Paris: Fayard, 1979; DARAKI, M. Dionysos et la Déesse Terre. Paris: Champs-Flammarion, 1994; DURAND, G. As estruturas antropológicas do imaginário, Introdução à arquetipologia geral. S. Paulo: Cultrix/Edusp, 1988.

20 MAFFESOLI, M. A sombra de Dionísio, Contribuição a uma sociologia da orgia. Rio: Graal, 1985.

21 GRIMAL, P. GRIMAL, P. Dicionário da mitologia grega e romana. Rio: Difel, 1993.

22 JUNG, C.G. 0 homem e seus símbolos. Rio de Janeiro: Imago, 1977.

23 AKOUN, A. (Org.) L'Europe, Mythe et Traditions. Paris: Brepols, 1990.

24 MIRCEA ELIADE. Méphistophélès et l'androgyne. Paris: Gallimard, 1962.

25 FERNANDEZ, D. Le rapte de Ganymède. Paris: Grasset, 1989. Para uma leitura atualizada da androgenia, ler: PAGLIA, C. Personas Sexuais, Arte e Decadência de Nefertite a Emily Dickinson. S. Paulo: Companhia das Letras, 1992.

26 MARCUSE, H. Eros e Civilização. Rio de Janeiro: Zahar, 1981.

27 SEVCENKO, N. Orfeu Extático na metrópole. MUNIZ DE BRITTO, J. Orf'eus. Rio de Janeiro: Editora Blocos, 1995; DÉTIENNE, M. L'écriture d'Orphée. Paris: Gallimard, 1989. 
28 QUEROLIN NETO, Luiz. "Psicanálise e Dionísio". In: MUNIZ SODRÉ (org.) Clínica e Sociedade. Rio: Coleção Persona, Gryphus, 1992. pp.156-163.

29 DELEUZE, G. Nietzsche et la Philosophie. Paris: PUF, 1962.

30 NIETZSCHE, F. A origem da tragédia. S. Paulo: Editora Moraes, 1984.

31 MAFFESOLI, M. Vagabondages Initiatiques. Paris: Le Livre de Poche, 1997.

32 FREUD, S. 0 mal estar na civilização. Col. Os Pensadores. S. Paulo: Abril Cultural.

33 NIETZSCHE, F. Assim falou Zaratustra, Um livro para todos e para ninguém. Rio: Civilização Brasileira, 1977.

34 ASSOUN. Freud et Nietzsche. Paris: PUF, 1980.

35 DÉTIENNE, M. Dionysos mis à mort. Paris, Seuil, 1979.

36 JAEGER, Werner. "La poésie comique d'Aristophane". In: Paidéia, la formation de l'homme grec. Paris: Gallimard, 1988 (1964). Pp. 408-433.

37 DARAKI, M. Dionysos et la Déesse Terre. Paris: ChampsFlammarion, 1994.

38 AKOUN, André (Org.) L'Europe, Mythe et Traditions. Paris: Brepols, 1990.

39 FREUD, S. 0 mal estar na civilização. In: Freud, col. Os Pensadores. S. Paulo: Abril Cultural, 1978; MARCUSE, Eros e Civilização. Rio de Janeiro: Zahar, 1981; ROSZAK, T. Contracultura. Petrópolis, Vozes, 1972.

40 SIMMEL, G. La tragédie de la culture. Paris, Rivage, 1988; MORIN, 0 paradigma perdido: a natureza do homem. Lisboa: Europa: América, s/d; MAFFESOLI, M. O Tempo das Tribos. Rio: Forense Universitária, 1987.

41 SAID, E. Orientalismo. S. Paulo: Companhia das Letras, 1998; _ "O orientalismo revisto". In: HOLANDA , H.B. (org.) Pós-modernismo e política. Rio: Rocco, 1991. 